\title{
Using plastic tips in artificial feeding of Rhipicephalus sanguineus sensu lato (Acari: Ixodidae) females
}

\author{
Uso de ponteiras plásticas na alimentação artificial de fêmeas de Rhipicephalus sanguineus
}

Jaqueline Rodrigues de Almeida Valim¹; Charles Passos Rangel ${ }^{1}$; Bruna de Azevedo Baêta²; Carla Carolina Dias Uzedo Ribeiro ${ }^{1}$; Matheus Dias Cordeiro ${ }^{1}$; Rafaella Câmara Teixeira ${ }^{1}$; Patrícia Barizon Cepeda ${ }^{1}$; Adivaldo Henrique da Fonseca ${ }^{1 *}$

\begin{abstract}
${ }^{1}$ Laboratório de Doenças Parasitárias, Departamento de Epidemiologia e Saúde Pública, Instituto de Veterinária, Universidade Federal Rural do Rio de Janeiro - UFRRJ, Seropédica, RJ, Brasil

${ }^{2}$ Curso de Medicina Veterinária, Universidade Severino Sombra - USS, Vassouras, RJ, Brasil
\end{abstract}

Received August 1, 2016

Accepted October 20, 2016

\begin{abstract}
This study evaluated the influence of the initial weight, feeding period and temperature on weight gain and biological parameters of the non-parasitic phase of partially engorged Rhipicephalus sanguineus females that were artificially fed using plastic tips as feeding devices. The device did not alter the oviposition of the females or any other parameters evaluated. Furthermore, it was observed that the temperature of the feeding the group did not affect the weight gain and biology of ticks. This device has great potential for the development of studies on bioagent transmission because it provides higher intake of blood by ixodid ticks.
\end{abstract}

Keywords: In vitro feeding, plastic tips, biological parameters, Rhipicephalus sanguineus.

\section{Resumo}

Este estudo avaliou a influência do peso inicial, período de alimentação e temperatura no ganho de peso e parâmetros biológicos da fase não parasitária, de fêmeas parcialmente ingurgitadas de Rhipicephalus sanguineus alimentadas artificialmente utilizando ponteiras plásticas como dispositivo de alimentação. O dispositivo não alterou a oviposição das fêmeas ou quaisquer outros parâmetros avaliados. Além disso, observou-se que a temperatura de alimentação do grupo não afetou o ganho de peso e a biologia dos carrapatos. Este dispositivo tem um grande potencial para o desenvolvimento de estudos sobre a transmissão de bioagentes, uma vez que proporciona maior ingestão de sangue por carrapatos ixodídeos.

Palavras-chave: Alimentação in vitro, ponteiras plásticas, parâmetros biológicos, Rhipicephalus sanguineus.

\section{Introduction}

The red or brown dog tick, Rhipicephalus sanguineus (Latreille, 1806), belongs to the family Ixodidae and is widely distributed throughout the world (LABRUNA, 2004). This species is highly prevalent in urban dogs (PAZ et al., 2008) and can occasionally parasitize other hosts, including humans (DANTAS-TORRES, 2010). This tick is an important vector for viruses, bacteria and protozoa that cause various diseases such as ehrlichiosis, anaplasmosis and babesiosis (SMITH et al., 1976; GARCÍA et al., 2007). In South America, a possible different vectorial competence for

*Corresponding author: Adivaldo Henrique da Fonseca. Laboratório de Doenças Parasitárias, Departamento de Epidemiologia e Saúde Pública, Instituto de Veterinária, Universidade Federal Rural do Rio de Janeiro - UFRRJ, CEP 23890-000, Seropédica, RJ, Brasil. e-mail: adivaldofonseca@yahoo.com.
Ehrlichia canis is showed, elucidating the taxonomic position of the $R$. sanguineus group species complex in the world, which includes at least two species in South America, designated as 'tropical species' and 'temperate species' (NAVA et al., 2012; CICUTTIN et al., 2015; MORAES-FILHO et al., 2015). Today, there are constant concerns and questions regarding the use of animals in scientific experiments. Improvement of artificial feeding techniques is extremely important for biological analyses and may contribute towards reducing the use of animals in scientific experimentation.

Among the devices for artificial feeding of ticks, natural and artificial membranes have made great progress (BONNET \& LIU, 2012). However, this technique is not easily adaptable to ixodid ticks. Capillary tubes have proved to be very effective for this group, showing promise for studies on pathogen isolation 
(RANGEL et al., 2008). Plastic tips have been used as a new alternative to automated artificial feeding techniques for ticks and were first described by Ribeiro et al. (2014) for feeding Dermacentor nitens.

The aims of the present study were to standardize artificial feeding through plastic tips for partially engorged females of $R$. sanguineus and to evaluate the influence of the technique on biological parameters as well as the influence of temperature on the application of this technique.

\section{Materials and Methods}

The experiment was conducted in accordance with the ethical protocol adapted from the Brazilian Society of Laboratory Animal Science (SBCAL) and had previously been approved by our institution's ethics committee (under the number 007330).

Partially engorged $R$. sanguineus group females (individuals from the third generation and forward) fed on rabbits (Oryctolagus cuniculus) were used. To initiate the colony, a total of 10 Engorged females of the $R$. sanguineus group were collected from naturally infested dogs under owners' consent in Seropédica city, state of Rio de Janeiro, southern Brazil (Latitude 22。 44' 38' S Longitude: 43 42' $27^{\prime}$ W Altitude: $26 \mathrm{~m}$ )

The rabbits were kept in individual cages and received commercial feed and water ad libitum. After collection, the ticks were washed with distilled water and dried.

The integrity of the mouthparts was examined with the aid of a stereomicroscope, and then the ticks were weighed on an analytical balance.

The feeding system used $1000 \mu \mathrm{l}$ plastic tips and followed the methods described by Ribeiro et al. (2014). The donor blood used in the feed was directly collected from the cephalic vein of a healthy dog through a vacuum system into a tube containing the anticoagulant sodium citrate. Subsequently, $200 \mu \mathrm{l}$ of blood were applied to each plastic tip, and this was replaced every 1.5 hours, thus allowing the ticks to receive fresh blood regularly. The angle for coupling the device to the mouthparts of the partially engorged females of $R$. sanguineus was approximately $25^{\circ}$ (Figure 1). This adaptation aimed to avoid extravasation of blood during feeding.

The experiment was divided into three steps. First, to ascertain the best weight range for initial artificial feeding through plastic tips, females were separated into four groups with 13 ticks per group. The four groups tested contained females weighing 20-35, 36-50, 51-65 and 66-80 mg. Each group was subjected to artificial feeding for 36 hours, at a controlled temperature of $37 \pm 1^{\circ} \mathrm{C}$ and relative humidity $(\mathrm{RH})$ above $80 \%$.

In a second experiment, partially engorged females that were within the best weight range that had been established in the first stage were divided into four groups, with 12 ticks per group. These were fed for periods of $6,12,24$ and 36 hours, at $37 \pm 1^{\circ} \mathrm{C}$ and relative humidity above $80 \%$, to determine the best duration of feeding for the species studied.

After the best initial weight and duration of artificial feeding were established; then, the third experiment aimed to evaluate the influence of temperature on the weight gain of females that

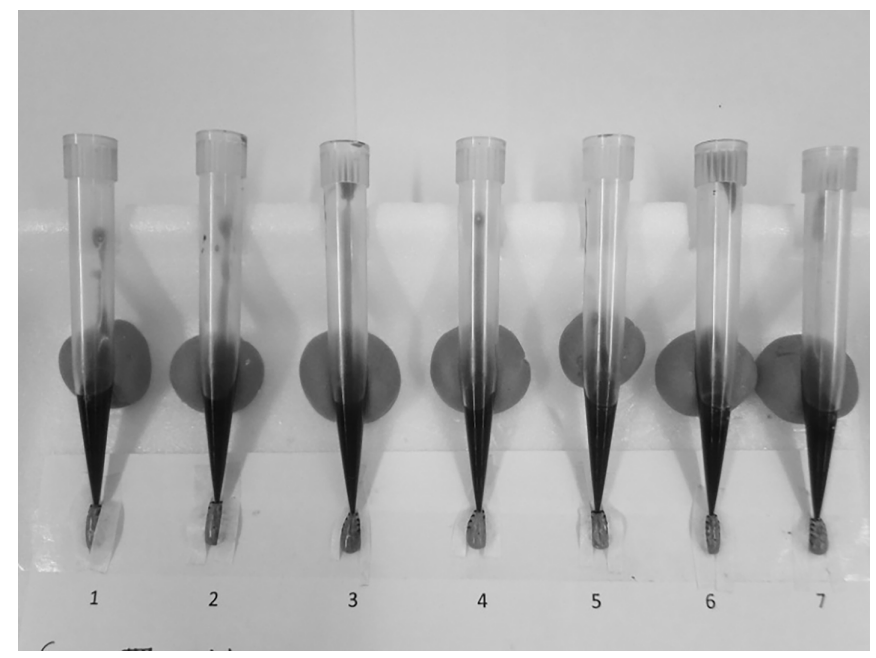

Figure 1. Partially engorged females of Rhipicephalus sanguineus during artificial feeding through plastic tips with canine citrated blood.

were fed artificially through plastic tips. For this experiment, partially engorged females were divided into two homogeneous groups with 13 ticks per group. The ticks were fed at controlled temperatures of $27^{\circ} \mathrm{C}$ and $37^{\circ} \mathrm{C}$.

After artificial feeding, the ticks were weighed and fixed with adhesive tape in a Petri dish and were kept at $27 \pm 1^{\circ} \mathrm{C}$ and relative humidity above $80 \%$ for subsequent evaluation of the biological parameters of the non-parasitic phase. The pre-laying period, laying period and weight of the egg mass were evaluated and nutritional efficiency and reproductive efficiency indexes were calculated in accordance with Bennett (1974) and Meléndez et al. (1998).

At all stages, control groups were formed from 13 ticks that had become completely engorged on rabbits and were randomly collected to ascertain the biological parameters of the non-parasitic phase.

All variables were checked for normality with a KolmogorovSmirnov test. Parametric tests were used because most variables were normally distributed. Statistical analyses consisting of analysis of variance (ANOVA) and Tukey's test were conducted, with a significance level of $5 \%$ to compare the means.

\section{Results}

The initial weight of the females subjected to artificial feeding through plastic tips influenced the final weight, although it was not significantly different among the ticks with an initial weight of 36 to $80 \mathrm{mg}$ (Table 1). Therefore, this group was used in the second experiment.

In assessing the best length of time for artificial feeding, the group that was allowed to feed for 36 hours (Table 1) showed the best mean weight gain and final weight, although this was not significantly different from the group that fed for 24 hours.

In the third experiment, ticks weighing between 36 and $80 \mathrm{mg}$ were fed for 24 hours at two different temperatures. There was no significant difference between the mean weight gains and final weights of females subjected to temperatures of $27^{\circ} \mathrm{C}$ and $37^{\circ} \mathrm{C}$ (Table 1). 


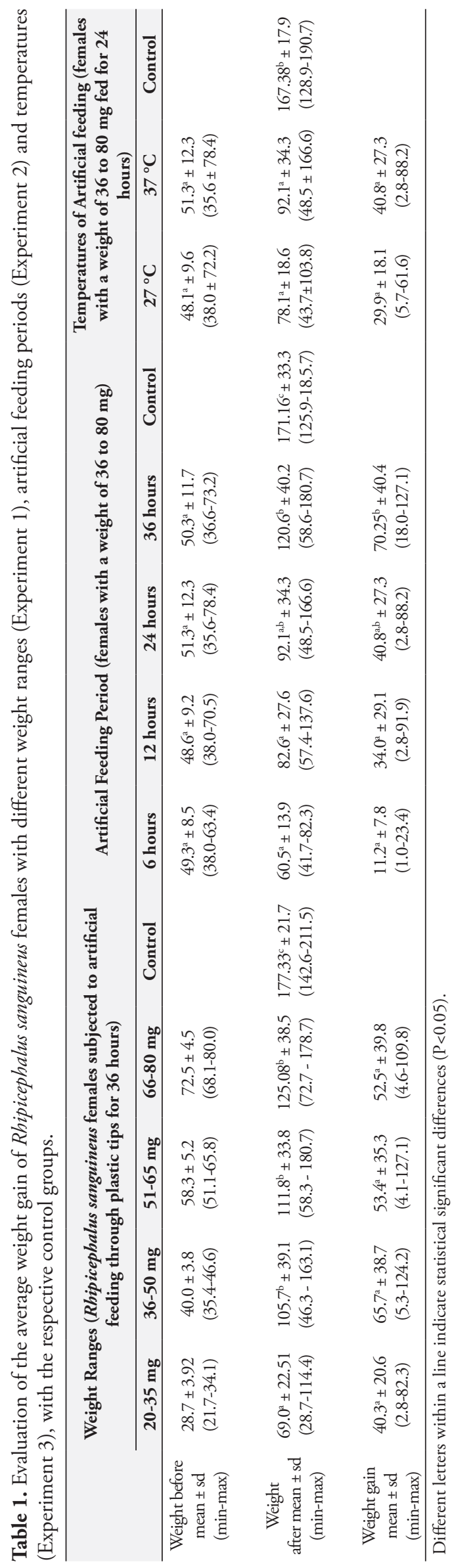


In the evaluation of the biological parameters, the artificial feeding decreased the weight of the egg mass; however, this technique did not influence the biology of the species studied.

\section{Discussion}

Weight measurement before and after the artificial feeding was an efficient parameter for evaluating the blood intake and weight gain of $R$. sanguineus females as also performed by De la Vega et al. (2000) and Rangel et al. (2008). There is a positive correlation between the blood volume intake and weight gained by the females (RECHAV et al., 1999).

The initial weight of a female subjected to artificial feeding influences the final weight of the ticks, as also observed by Rangel et al. (2008). From analysis of the data from the first experiment, Table 1 shows that the weight gain of the ticks increased with higher ranges of initial tick weight. In a study on artificial feeding through capillaries using the same tick species, Cunha et al. (2010) obtained weight gain results that were lower than measured in the present study.

The observed weight gain was related to the period of exposure to the plastic tips. Cunha et al. (2010) showed that the weight of the artificially fed groups increased as the time exposed to the capillary increased, but the results in tick weight were lower than tick weight using the plastic tip method. The present study was a record of an expressive blood intake by $R$. sanguineus ticks using the artificial feeding technique.

This new device has great potential for the development of studies on bioagent transmission because it provides a higher intake of blood by ixodid ticks. During feeding, ticks ingest a very large quantity of blood over a relatively long period of time, thereby increasing the chance of ingesting a pathogen (BONNET \& LIU, 2012).

According to the study by Chabaud (1950), the success of artificial feeding depends on standardization of a suitable temperature for the intake of the diets offered. However, this was not observed in the present study, which suggests that in a situation in which working under controlled conditions is impossible, there would be no interference in the biological parameters of the species in question.

Artificial feeding with the new device did not interfere with the biology of the ticks, as similarly observed in the species $D$. nitens by Ribeiro et al. (2014).

\section{Conclusions}

The data demonstrated that the artificial feeding of partially engorged $R$. sanguineus females through plastic tips using canine citrated blood is appropriate because this technique presented advantages over the capillary tube technique, thereby increasing weight gain.

This new device has great potential for development of studies on bioagent transmission because it provides higher blood intake by ixodid ticks.

\section{References}

Bennett GF. Oviposition of Boophilus microplus (Canestrini) (Acarida: Ixodidae). II. Influence of temperature, humidity and light. Acarologia 1974; 16(2): 251-257. PMid:4466310.

Bonnet S, Liu XY. Laboratory artificial infection of hard ticks: a tool for the analysis of tick-borne pathogen transmission. Acarologia 2012; 52(4): 453-464. http://dx.doi.org/10.1051/acarologia/20122068.

Chabaud AG. Sur la nutrition artificielle des tiques. Ann Parasitol Hum Comp 1950; 25(1-2): 42-47. PMid:13181220.

Cicuttin GL, Tarragona EL, Salvo MN, Mangold AJ, Nava S. Infection with Ehrlichia canis and Anaplasma platys (Rickettsiales: Anaplasmataceae) in two lineages of Rhipicephalus sanguineus sensu lato (Acari: Ixodidae) from Argentina. Ticks Tick Borne Dis 2015; 6(6): 724-729. PMid:26100492. http://dx.doi.org/10.1016/j.ttb'dis.2015.06.006.

Cunha NC, Rangel CP, Piranda EM, Rezende J, Teixeira RC, Fonseca AH. Assessment of weight gain and biological parameters of Rhipicephalus sanguineus females fed artificially via capillary tubes. Cienc Rural 2010; 40(4): 928-933. http://dx.doi.org/10.1590/S0103-84782010000400028.

Dantas-Torres F. Biology and ecology of the brown dog tick, Rhipicephalus sanguineus. Parasit Vectors 2010; 3(1): 26. PMid:20377860. http://dx.doi. org/10.1186/1756-3305-3-26.

De La Vega R, Diaz G, Finlay L. Artificial feeding of Boophilus microplus (Acari: Ixodidae) through micropipettes. Ann NY Acad Sci 2000; 916(1): 315-319. PMid:11193640. http://dx.doi.org/10.1111/j.1749-6632.2000. tb05307.x.

García ME, Moissant E, Pérez A, Quijada J, Simoes D, García H. Comportamiento natural de las fases no parasíticas de Rhipicephalus sanguineus (Latreille, 1806) (Acari: Ixodidae) en un bioterio canino de Venezuela. Rev Cient 2007; 17(6): 566-571.

Labruna MB. Biologia-ecologia de Rhipicephalus sanguineus (Acari: Ixodidae). Rev Bras Parasitol Vet 2004; 13(S1): 123-124.

Meléndez RD, Coronado A, Mujica F, Cerutti F, Mosquera O. Levels of natural resistance two Boophilus microplus (Acari: Ixodidae) in Carora breed bulls. Rev Biol Trop 1998; 46(3): 691-696. PMid:10347818.

Moraes-Filho J, Krawczak FS, Costa FB, Soares JF, Labruna MB. Comparative Evaluation of the Vector Competence of Four South American Populations of the Rhipicephalus sanguineus Group for the Bacterium Ehrlichia canis, the Agent of Canine Monocytic Ehrlichiosis. PLoS One 2015; 10(9): e0139386. PMid:26414283. http://dx.doi. org/10.1371/journal.pone.0139386.

Nava S, Mastropaolo M, Venzal JM, Mangold AJ, Guglielmone AA. Mitochondrial DNA analysis of Rhipicephalus sanguineus sensu lato (Acari: Ixodidae) in the Southern Cone of South America. Vet Parasitol 2012; 190(3-4): 547-555. PMid:22818199. http://dx.doi.org/10.1016/j. vetpar.2012.06.032.

Paz GF, Leite RC, Oliveira PR. Controle de Rhipicephalus sanguineus (Latreille, 1806) (Acari: Ixodidae) no canil da escola de veterinária da UFMG, Belo Horizonte, Minas Gerais, Brasil. Rev Bras Parasitol Vet 2008; 17(1): 41-44. PMid:18554440. http://dx.doi.org/10.1590/ S1984-29612008000100009. 
Rangel CP, Cunha NC, Rezende J, Silva FJM, Corrêa FN, Teixeira RC, et al. Alimentação artificial por meio de tubos capilares de fêmeas parcialmente ingurgitadas do carrapato Dermacentor (Anocentor) nitens. Rev Bras Parasitol Vet 2008;17(Suppl 1): 35-39. PMid:20059812.

Rechav Y, Zyzak M, Fielden LJ, Childs JE. Comparison of methods for introducing and producing artificial infection of ixodid ticks (Acari: Ixodidae) with Ehrlichia chaffeensis. J Med Entomol 1999; 36(4): 414 419. PMid:10467766. http://dx.doi.org/10.1093/jmedent/36.4.414.
Ribeiro CCDU, Baêta BA, Valim JRA, Teixeira RC, Cepeda PB, Silva $\mathrm{JB}$, et al. Use of plastic tips in artificial feeding of Dermacentor (Anocentor) nitens females Neumann, 1897 (Acari: Ixodidae). Ticks Tick Borne Dis 2014; 5(6): 689-692. PMid:25132536. http://dx.doi.org/10.1016/j. ttbdis.2014.05.012.

Smith RD, Sells DM, Stephenson EH, Ristic M, Huxoll DL. Development of Ehrlichia canis, causative agent of canine ehrlichiosis, in the tick Rhipicephalus sanguineus and its differentiation from a symbiotic Rickettsia. Am J Vet Res 1976; 37(2): 119-126. PMid:944000. 